\title{
Measuring the Relationship between Transformational Leadership and Employees' Job Engagement in Hotels
}

\author{
Jehan El Amir Abbas \\ Tamer Mohamed Amer \\ Faculty of Tourism and Hotels, Sadat City University
}

\begin{abstract}
This paper examines the relationship between transformational leadership dimensions and employees' job engagement in Cairo five- star hotels. It explores how participants of employees deem transformational leader and how this leader helps them to keep vigorous, dedicated, and absorbed at work. The paper concludes with a discussion of the importance of supervisors spending time teaching, coaching, developing their employees, and how this makes the employees more willing to dedicate extra effort and be more engaged in the job performance with the aim of producing world class levels of innovation, enhancing service quality and generating competitive advantage.
\end{abstract}

Keywords: Transformational leadership, Job engagement, Hotel management

\section{Introduction}

The concept of job engagement has gained its importance on account of its significant value for job performance. ${ }^{1,2}$ Recent reviews have listed various different definitions of job engagement. ${ }^{3}$ We follow the concept of Schaufeli \& Bakker, ${ }^{4}$ according to which job engagement is a positive, affective-motivational work-related state that is characterized by vigor, dedication, and absorption. Vigor refers to high levels of energy and mental resilience while working. Dedication refers to a sense of significance, enthusiasm, inspiration, pride, and challenge. Finally, absorption is characterized by being fully concentrating and happily engrossed in one's work, whereby time passes quickly and one has difficulties with detaching from work. 4,5

\section{Literature Review}

\section{Leadership styles and job engagement}

b. M. Bass differentiated between three broad leadership styles that vary from individual consideration and support for the employee (transformational style) to a proportional exchange between the leader and the employee (transactional style), or to no interest at all for the employee (laissez-faire style). ${ }^{6} \mathrm{We}$ do not expect that the latter two leadership styles contribute to employees' job engagement substantially, because they lack motivational power and inspirational appeal. Indirect evidence for this contention comes from an experimental study by Van Vugt, Jepson, Hart \& de D. Cremer. ${ }^{7}$ Participants were randomly assigned to one of three groups, individuals were asked whether they wanted to stay in the same group or join a different group for a subsequent task. The results suggested that participants were more likely to leave the group when they were in the condition with the transactional or the laissez-faire leader, in contrast with the transformational leader. When confronted with a transactional leader, group members were unhappy with the limited amount of control they had over the decision processes, while when confronted with a laissez-faire leader participants did have control, but they were not motivated to invest additional effort.

\section{Transformational leadership and job engagement}

Transformational leadership is defined as leadership behavior that transforms the norms and values of the employees, whereby the leader motivates the workers to perform beyond their own expectations. ${ }^{8}$ This leadership style focuses on the enhancement of the followers' involvement with the goals of their organization. ${ }^{6}$ A central aspect of this leadership style is the inspiring vision of the supervisor. ${ }^{9}$ Transformational leadership is traditionally divided into four components: (1) inspirational motivation; (2) idealized influence; (3) individual consideration; and (4) intellectual stimulation. ${ }^{9,10,11}$ Inspirational motivation focuses on the communication of an appealing vision of the future and the use of symbols to articulate this vision. ${ }^{9}$ In other words, the supervisor is optimistic and enthusiastic about the future. ${ }^{12}$ Idealized influence refers to behaviors like showing that benefits of the group are more important than benefits of the individual, demonstrating high ethical norms, and being a role model for the subordinates. ${ }^{12}$ Inspirational motivation and idealized influence together are also called "charisma". Charismatic leaders have a positive influence on their subordinates and can change the self-focus of the employees to a collective focus. ${ }^{13}$ As a result, subordinates become more involved in the vision of the leader and more willing to make sacrifices for that vision. ${ }^{14}$

The third component of transformational leadership, individual consideration, refers to coaching, supporting and stimulating subordinates. The supervisor acknowledges followers' feelings and emotions as well as their need to grow and develop themselves. ${ }^{9}$ Employees are seen as unique individuals who need specific, individual attention that is congruent with the developmental phase they are in. ${ }^{15}$ The fourth and last component of transformational leadership is 
called intellectual stimulation, which means that the supervisor challenges the subordinate to see problems from a different perspective. In this way, the supervisor makes the workers active thinkers within the organization and consequently, the employees become more involved with the organization.

It has been found that employees' feelings of involvement, cohesiveness, commitment, potency, and performance are enhanced by the transformational leadership style. ${ }^{16}$ An employee who receives support, inspiration and quality coaching from the supervisor, is likely to experience work as more challenging, involving and satisfying, and consequently, to become highly engaged with the job tasks. Taking into account that satisfaction with one's coworkers is related to job engagement ${ }^{17}$, it is conceivable that satisfaction that arises from working with a transformational leader may have similar results. On the basis of these findings we predict that the transformational leadership style enhances employees' job engagement.

\section{Research Hypotheses}

H1: There is a statistically significant relationship between transformational leadership and achieving employees' job engagement.

H2: There is a significant difference among hotels' supervisors regarding their demographic profile and characteristics of transformational leadership.

\section{Method \\ Participants}

Total response to the survey included 150 participants. This resulted in a total of 139 forms valid for analysis, including 18 women and 121 men. All participants are working in several revenue centers in luxury hotels at Cairo (food and beverage, housekeeping, and front office). Other demographic information were collected regarding the participant hotel and his/her supervisor, in order to assess differences among individuals. Questions included management pattern, number of rooms, supervisor's gender, and age. (see Table 2 for frequencies of the sample).

\section{Measures}

Transformational leadership dimensions are the first part in the survey. To measure the leadership style of participants' direct supervisors, Bass and Avolio's Multidimensional Leadership Questionnaire (MLQ) ${ }^{10}$ was used. Responses were rated on a Likert-type scale ranging from 1 (Strongly disagree) to 5 (Strongly agree). The 20 items measured transformational leadership (Individualized Consideration, Inspirational Motivation, Idealized Influence, and Intellectual Stimulation).

The second part of the questionnaire concerns employee job engagement. To measure the job engagement of the employee, the Utrecht Job Engagement Scale (UWES) was used. ${ }^{18}$ UWES includes the three dimensions of engagement - vigor (6 items), dedication (5 items), and absorption (6 items) - to create a 17 items measure. Responses were rated on a scale ranging from 1 (Strongly disagree) to 5 (Strongly agree). Since this part focuses on engagement as a psychological state, it measures engagement as an indicator of employee cognitive and emotional states.

\section{Statistical analysis}

SPSS (version 17.0) was used to analyze the preliminary data, including: descriptive statistics, Spearman's correlation analysis. Mann-Whitney U and Kruskal-Wallis H tests were used to identify the difference between groups.

\section{Results and Discussion}

\section{Reliability analysis}

Crombach's alpha was used in this research to measure the internal consistency of the instrument. It is the most accepted formula for assessing reliability of a measurement with multi-point items. ${ }^{19}$ The study determined Crombach's alpha to ensure that the specified items are sufficient in their representation of the underlying constructs. Reliability alone is not sufficient to judge an instrument as adequate. Therefore, validity is required to validate the constructs of this study. In order to obtain the content validity, existing scales were identified from the literature and interviews were conducted with practitioners from hotel industry, asking them to give their comments on the instrument. In addition, F. Jacob suggested that Crombach's alpha should meet the recommended significance of 0.70 or higher. ${ }^{20}$ The coefficient alpha of individual consideration, inspirational motivation, idealized influence, intellectual stimulation, employee engagement, and the overall of instrument reliability and validity coefficient are presented in Table (1). 
Measuring the Relationship between Transformational Leadership

Table (1): Coefficient of reliability and validity of the questionnaire

\begin{tabular}{|l|l|c|c|}
\hline \multirow{4}{*}{\begin{tabular}{l} 
Constructs \\
\multirow{4}{*}{$\begin{array}{l}\text { Transformational } \\
\text { leadership }\end{array}$}
\end{tabular}} & Individual Consideration & 4 & Crombach's Alpha \\
\cline { 2 - 4 } & Inspirational Motivation & 4 & 0.870 \\
\cline { 2 - 4 } & Idealized Influence & 8 & 0.837 \\
\cline { 2 - 4 } & Intellectual Stimulation & 4 & 0.933 \\
\cline { 2 - 4 } & Overall & $\mathbf{2 0}$ & 0.862 \\
\hline \multirow{4}{*}{ Engagement } & Vigor & 6 & $\mathbf{0 . 9 0 4}$ \\
\cline { 2 - 4 } & Dedication & 6 & 0.927 \\
\cline { 2 - 4 } & Absorption & 6 & 0.872 \\
\cline { 2 - 4 } & Overall & $\mathbf{1 7}$ & 0.872 \\
\hline & & $\mathbf{3 7}$ & $\mathbf{0 . 9 2 4}$ \\
\hline
\end{tabular}

The above table shows that the coefficient of Crombach's alpha for all constructs of the questionnaire had relatively high alpha coefficient scores $(0.96 .2 \%)$. Since all constructs of the questionnaire had a relatively accepted reliability coefficient, it can be assured that the used items included in the questionnaire are valid to measure what it is supposed to measure.

\section{Descriptive statistics}

Before assessing the hypotheses, the frequencies and percentage of demographic data for employees and supervisors were displayed in Table 2 .

Table (2): Descriptive statistics of demographic variables

\begin{tabular}{|l|c|c|}
\hline \multicolumn{1}{|c|}{ Gender } & Frequency & Percent \\
\hline Males Age & 121 & 87.1 \\
\hline Females & 18 & 12.9 \\
\hline Total & 139 & 100.0 \\
\hline \multicolumn{1}{|c|}{ Education } & Frequency & Percent \\
\hline Less than 35 years & 46 & 33.1 \\
\hline 35 to less than 40 & 66 & 47.5 \\
\hline 40 to less than 45 & 14 & 10.1 \\
\hline 45 to less than 50 & 10 & 7.2 \\
\hline More than 50 & 3 & 2.2 \\
\hline Total & 139 & 100.0 \\
\hline & Frequency & Percent \\
\hline High School & 66 & 47.5 \\
\hline College & 68 & 48.9 \\
\hline Post graduate & 5 & 3.6 \\
\hline Total & 139 & 100.0 \\
\hline \multicolumn{1}{|c|}{ Supervisor gender } & 139 & 90.6 \\
\hline Male & 139 & 100.0 \\
\hline Female & & Frequency \\
\hline Total & 126 & \\
\hline Table (2) & 13 & \\
\hline
\end{tabular}

Table (2) continue

\begin{tabular}{|l|c|c|}
\hline \multicolumn{1}{|c|}{ Supervisor age } & Frequency & Percent \\
\hline Less than 35 years & 4 & 2.9 \\
\hline 35 to less than 40 & 37 & 26.6 \\
\hline 40 to less than 45 & 14 & 10.1 \\
\hline More than 45 years & 84 & 60.4 \\
\hline Total & 139 & 100.0 \\
\hline
\end{tabular}

The gender of respondents was 121 males and 18 females for total respondents as shown in table (2). Average employees' age was $47.5 \%$, ranging from 35 to less than 40 years old, and this was the largest percentage of 
respondents. The majority of respondents (48.9\%) have obtained a bachelor's degree; while a small percentage (3.6\%) have obtained post graduate degree. When asking employees about their immediate supervisors' gender, their response referred to that 90.6 were males. As for the age of supervisors, the study reveals that $60.4 \%$ of them were more than 45 years old (table 2). The means and standard deviation of transformational leadership dimensions, and employee job engagement (vigor, dedication, absorption), were calculated and displayed in Table (3).

Table (3) Means and standard deviation of variables

\begin{tabular}{|c|c|c|c|}
\hline Variable & $\mathbf{N}$ & Mean (M) & Standard deviation (SD) \\
\hline Transformational leadership & $\mathbf{1 3 9}$ & $\mathbf{2 . 8 3 0}$ & $\mathbf{1 . 1 0 9}$ \\
\hline Individual Consideration & $\mathbf{1 3 9}$ & $\mathbf{2 . 8 5 2}$ & $\mathbf{1 . 1 6 9}$ \\
\hline Inspirational Motivation & $\mathbf{1 3 9}$ & $\mathbf{2 . 8 1 1}$ & $\mathbf{1 . 1 3 3}$ \\
\hline Idealized Influence & $\mathbf{1 3 9}$ & $\mathbf{2 . 8 5 9}$ & $\mathbf{1 . 2 1 0}$ \\
\hline Intellectual Stimulation & $\mathbf{1 3 9}$ & $\mathbf{2 . 7 6 7}$ & $\mathbf{1 . 1 7 9}$ \\
\hline Engagement & $\mathbf{1 3 9}$ & $\mathbf{2 . 7 3 5}$ & $\mathbf{0 . 9 3 5}$ \\
\hline Vigor & $\mathbf{1 3 9}$ & $\mathbf{3 . 2 2 3}$ & $\mathbf{1 . 0 1 1}$ \\
\hline Dedication & 139 & 3.147 & 1.025 \\
\hline Absorption & 139 & 3.230 & .971 \\
\hline
\end{tabular}

The mean scores of transformational leadership items ranged from $(M=2.767)$ to $(M=2.859)$. The fact that ratings fell between 2.00 and 3.00 on the 5-point scale associated with the MLQ indicates that supervisors felt somewhat responsible for the decisions they made with regard to their employees. It also reveals that supervisors consider employees as having different needs and abilities, creating a vision for their future, emphasizing the importance of having a collective sense of mission, seeking differing perspectives when solving problems, and communicating with employees in a transformational manner. Employee job engagement items were also measured on a 5-point scale and mean scores ranged from $(M=3.147)$ to $(M=3.230)$. Since scores fell between 3.00 and 4.00 , it was inferred that employees usually felt enthusiastic and immersed at work.

\section{Correlation between variables.}

Spearman's correlation coefficient between transformational leadership (with its dimensions) and employee job engagement (with its dimensions) were computed. All correlations were found positive and significantly correlated. This is seen in Table 4.

Table (4) Correlation matrix between variables of the study

\begin{tabular}{|c|c|c|c|c|c|}
\hline $\begin{array}{l}\text { Dimensions of } \\
\text { Transformational } \\
\text { leadership }\end{array}$ & & 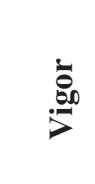 & .气 & 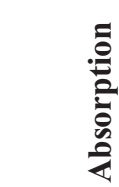 & 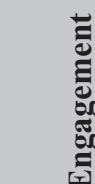 \\
\hline $\begin{array}{l}\text { Individual } \\
\text { Consideration }\end{array}$ & $\begin{array}{l}\text { Correlation } \\
\text { Sig. } \\
\text { N }\end{array}$ & $\begin{array}{l}0.471 \\
0.000 \\
139\end{array}$ & $\begin{array}{l}0.574 \\
0.009 \\
139\end{array}$ & $\begin{array}{l}0.462 \\
0.022 \\
139\end{array}$ & $\begin{array}{l}0.559 \\
0.000 \\
139\end{array}$ \\
\hline $\begin{array}{l}\text { Inspirational } \\
\text { Motivation }\end{array}$ & $\begin{array}{l}\text { Correlation } \\
\text { Sig. } \\
\text { N }\end{array}$ & $\begin{array}{l}0.464 \\
0.000 \\
139\end{array}$ & $\begin{array}{l}0.321 \\
0.008 \\
139\end{array}$ & $\begin{array}{l}0.347 \\
0.004 \\
139\end{array}$ & $\begin{array}{l}0.398 \\
0.000 \\
139\end{array}$ \\
\hline Idealized Influence & $\begin{array}{l}\text { Correlation } \\
\text { Sig. } \\
\text { N }\end{array}$ & $\begin{array}{l}0.517 \\
0.000 \\
139\end{array}$ & $\begin{array}{l}0.381 \\
0.001 \\
139\end{array}$ & $\begin{array}{l}0.366 \\
0.002 \\
139\end{array}$ & $\begin{array}{l}0.451 \\
0.000 \\
139\end{array}$ \\
\hline $\begin{array}{l}\text { Intellectual } \\
\text { Stimulation }\end{array}$ & $\begin{array}{l}\text { Correlation } \\
\text { Sig. } \\
\text { N }\end{array}$ & $\begin{array}{l}0.564 \\
0.000 \\
139\end{array}$ & $\begin{array}{l}0.383 \\
0.008 \\
139\end{array}$ & $\begin{array}{l}0.366 \\
0.004 \\
139\end{array}$ & $\begin{array}{l}0.478 \\
0.000 \\
139\end{array}$ \\
\hline $\begin{array}{l}\text { Transformational } \\
\text { leadership }\end{array}$ & $\begin{array}{l}\text { Correlation } \\
\text { Sig. } \\
\text { N }\end{array}$ & $\begin{array}{l}0.540 \\
0.000 \\
139\end{array}$ & $\begin{array}{l}0.405 \\
0.000 \\
139\end{array}$ & $\begin{array}{l}0.395 \\
0.000 \\
139\end{array}$ & $\begin{array}{l}0.489 \\
0.000 \\
139\end{array}$ \\
\hline
\end{tabular}

As far as the variables of transformational leadership are concerned, moderate significant correlation was found between individual consideration and employee job engagement $(\mathrm{r}=0.55, \mathrm{p}<.05)$. This indicates that when hotel 


\section{Measuring the Relationship between Transformational Leadership}

supervisors spent time teaching, coaching, helping, and developing their employees, the latter were more likely to energize and dedicate extra effort at work and achieve better job performance. A relatively low correlation was found between inspirational motivation and engagement of employee $(\mathrm{r}=0.39, \mathrm{p}<.05)$, indicating a relationship between the supervisor's ability to articulate the vision for the future, and the continuity of work for very long periods of time.

Furthermore, a strong correlation was observed between the transformational leadership and employee job engagement items, $(\mathrm{r}=0.48, \mathrm{p}<.05)$. Transformational leadership accounted for a statistically significant relationship with employee job engagement scores and played an important role in producing engaged employees, so that, the first hypothesis was confirmed.

\section{Differences between variables}

This study depended on Kruskal-Wallis test to measure the significant difference $(p<.05)$ between age groups of employees concerning their job engagement (see Table 5). The results highlighted that age group of more than 45 years old (mean rank $=99.55$ ) has a strong evidence of engagement to their jobs - perhaps as a result of long tenure in the hotel; they got acquainted with job's negative and positive aspects and could not start a new career.

Table (5) Differences between employees according to their age groups

\begin{tabular}{|c|c|c|c|c|c|}
\hline \multirow{6}{*}{$\begin{array}{l}\text { Transformational } \\
\text { leadership }\end{array}$} & employees Age & $\mathbf{N}$ & $\%$ & Mean Rank & Sig. \\
\hline & Less than 35 years & 46 & 33.09 & 57.64 & \multirow{5}{*}{0.015} \\
\hline & 35 to less than 40 & 66 & 47.48 & 57.63 & \\
\hline & 40 to less than 45 & 14 & 9.35 & 60.92 & \\
\hline & More than 45 & 13 & 10.08 & 99.55 & \\
\hline & Total & 139 & 100 & & \\
\hline
\end{tabular}

On the other hand, the significant differences (Sig. 0.034) between the genders of supervisors concerning the acquisition of the attributes of transformational leadership were investigated by Mann-Whitney and Kruskal-Wallis tests. Table (6) illustrates that female supervisors have more characteristics of transformational leadership (mean rank $=$ 73.62). This may be due to females wishing to prove themselves more than males in the field of hotel industry, especially at the multinational hotel companies. According to Kruskal-Wallis Test, there is a significant difference among supervisors regarding their age groups (Sig. 0.006). Age category from less than 35 years has the attributes of transformational leadership as they have the challenge and enthusiasm of the beginning of career (Table 6). So that, it can argued that the second hypothesis of the study was proven also.

Table (6) Differences between respondents' gender and age concerning transformational leadership attributes

\begin{tabular}{|l|l|c|c|c|}
\hline \multirow{4}{*}{$\begin{array}{l}\text { Transformational } \\
\text { leadership }\end{array}$} & \multicolumn{1}{|c|}{ Supervisor Gender } & N & $\begin{array}{c}\text { Mean } \\
\text { Rank }\end{array}$ & \multirow{2}{*}{ Sig.(2 tailed) } \\
\hline \multirow{4}{*}{$\begin{array}{l}\text { Transformational } \\
\text { leadership }\end{array}$} & Male & 126 & 69.63 & \multirow{2}{*}{0.034} \\
\cline { 2 - 4 } & Female & 13 & 73.62 & \\
\cline { 2 - 4 } & Total & 139 & & \multirow{2}{*}{ Sig.(2 tailed) } \\
\cline { 2 - 4 } & \multicolumn{1}{|c|}{ Supervisor Age } & N & $\begin{array}{c}\text { Mean } \\
\text { Rank }\end{array}$ & \multirow{2}{*}{0.006} \\
\cline { 2 - 4 } & Less than 35 years & 4 & 81.25 & \\
\cline { 2 - 4 } & 35 to less than 40 & 37 & 79.08 & \\
\cline { 2 - 4 } & 40 to less than 45 & 14 & 69.04 & \\
\cline { 2 - 4 } & More than 45 years & 84 & 65.63 & \\
\cline { 2 - 4 } & Total & 139 & & \\
\hline
\end{tabular}

\section{Conclusion}

It was found that when hotel supervisors spend time teaching, coaching, helping, and developing their employees, employees are more likely to dedicate extra effort at work, and be more engaged in the job performance. The results of this study highlighted that employees of age group of more than 45 years old have strong job engagement as a result of high tenure in the hotel, the acquaintance of job, and their inability to start a new career in other organizations. As far as gender is concerned, female supervisors have got better transformational leadership dimensions than males. According to the applied statistical tests, supervisors of age category of less than 35 years old have the attributes of transformational leadership, such as enthusiasm and the challenge of starting a career.

In job engagement people employ and express themselves physically, cognitively, and emotionally during their role performances. The cognitive aspect of employee engagement concerns employees' beliefs $\grave{a}$ propos the hotel, its leaders, and working conditions. The emotional aspect concerns how employees positive or negative attitudes 
towards the hotel. The physical aspect of employee engagement concern the physical energies exerted by individuals to accomplish their duties. ${ }^{21}$ It is concluded that engagement means to be psychologically as well as physically devoted when occupying and performing an organizational role.

\section{Recommendations}

Transformational leadership is an important tool for employees' engagement; it helps employees to keep vigorous, dedicated and absorbed. Hotel management should be aware of that critical issue. Ardent workforce is strongly satisfied and is much willing to stay with its employers. Hotels that truly work to get their staff engaged and inspired usually produce world class levels of innovation, productivity and enhanced performance. This, in turn, results in gaining considerable competitive advantage.

\section{References}

1. Bakker, A. (2009), Building engagement in the workplace, In C. Cooper \& R. Burke (Eds.), The peak performing organization, London: Routledge, pp. 50-72.

2. Schaufeli, W.B. \& Salanova, M. (2007), Work engagement: An emerging psychological concept and its implications for organizations, In Gilliland, S.W., Steiner, D.D. and Skarlicki, D.P. (Eds), "Research in social issues in management", Information Age Publishers, Greenwich, CT, pp. 135-177.

3. Macey, W. H., \& Schneider, B. (2008), The meaning of employee engagement, Industrial and Organizational Psychology: Perspectives on Science and Practice, 1, pp. 3-30.

4. Schaufeli, W.B. \& Bakker, A.B. (2004), Job demands, job resources and their relationship with burnout and engagement: A multi-sample study, Journal of Organizational Behaviour, 25, pp. 293-315.

5. Schaufeli, W. B., \& Bakker, A. B. (2010), Defining and measuring work engagement: Bringing clarity to the concept. In A. B. Bakker \&M. P. Leiter (Eds.), Work engagement: A handbook of essential theory and research, New York: Psychology Press, pp. 10-24.

6. Bass, B. M. (1985), Leadership performance beyond expectations, Academic Press, New York.

7. Van Vugt, M., S.F. Jepson, C.M. Hart, \& de D. Cremer. (2004), Autocratic leadership in social dilemmas: A threat to group stability. Journal of Experimental Social Psychology, 40(1), pp. 1-13.

8. Yukl, G. A. (1989), Leadership in organizations, Second edition, Englewood Cliffs, NJ: Prentice Hall.

9. Den Hartog, D. N., Koopman, P. L., \& van Muijen, J. J. (1997), Inspirerend leiderschap in organisaties, Schoonhoven: Academic Service.

10. Bass, B. M., \& Avolio, B. J. (1990), Improving organizational effectiveness through transformational leadership. Thousand Oaks: Sage Publications.

11. Chemers, M. M. (2000), Leadership research and theory: A functional integration, Group Dynamics: Theory, Research, and Practice, 4, pp. 27-43.

12. Bono, J. E., \& Judge, T. A. (2004), Personality and transformational and transactional leadership: A metaanalysis. The Journal of Applied Psychology, 89, 901-910.

13. Yorges, S. L., Weiss, H. M., \& Strickland, O. J. (1999), The effect of leader outcomes on influence, attributions, and perceptions of charisma, The Journal of Applied Psychology, 84, pp. 428-436.

14. House, R. J., \& Howell, J. M. (1992), Personality and charismatic leadership, The Leadership Quarterly, 3, pp. 81-108.

15. Avolio, B. J., \& Bass, B. M. (1995), Individual consideration viewed at multiple levels of analysis: A multilevel framework for examining the diffusion of transformational leadership, The Leadership Quarterly, 6, pp. 199-218.

16. Shamir, B., House, R. J., \& Arthur, M. B. (1993), The motivational effect of charismatic leadership: A selfconcept based theory, Organization Science, 4, pp. 577-594.

17. Avery, D. R., McKay, P. F., \& Wilson, D. C. (2007), Engaging the aging workforce: The relationship between perceived age similarity, satisfaction with coworkers, and employee engagement, The Journal of Applied Psychology, 92, pp. 1542-1556.

18. Schaufeli, W.B., Bakker, A.B., \& Salanova, M. (2006), The measurement of work engagement with a short questionnaire: A cross-national study, Educational and Psychological Measurement, 66, pp. 701-715.

19. Peter, J. P. (1979), Reliability: A review of psychometric basics and recent marketing practices, Journal of Marketing Research, XVI(February), pp. 6-17.

20. Jacob, F. (2006), Preparing industrial suppliers for customer integration, Industrial Marketing Management, 35(1), pp. 45-56.

21. Kahn, W. A. (1990), Psychological conditions of personal engagement and disengagement at work, Academy of Management Journal, 33, pp. 692-724. 


\section{Questionnaire}

This questionnaire is to describe dimensions of leadership as you perceive. Please answer all items on this sheet. Twenty descriptive statements are listed below. Judge how frequently each statement fits you.

\section{SECTION I}

\begin{tabular}{|c|c|c|c|c|c|}
\hline STATEMENT & \multicolumn{5}{|c|}{ SCALE } \\
\hline Individual Consideration & 1 & 2 & 3 & 4 & 5 \\
\hline 1. My manager spends time teaching and coaching. & & & & & \\
\hline 2. My manager treats me as an individual rather than just as a member of a group. & & & & & \\
\hline 3. My manager helps me to develop my strengths. & & & & & \\
\hline 4. My manager considers me as having different needs, abilities and aspirations from others. & & & & & \\
\hline Inspirational Motivation Measure & 1 & 2 & 3 & 4 & 5 \\
\hline 5. My manager talks optimistically about the future. & & & & & \\
\hline 6. My manager talks enthusiastically about what needs to be accomplished. & & & & & \\
\hline 7. My manager articulates a compelling vision of the future. & & & & & \\
\hline 8. My manager expresses confidence that goals will be achieved. & & & & & \\
\hline Idealized Influence Measure & 1 & 2 & 3 & 4 & 5 \\
\hline 9. My manager instills pride in me for being associated with $\mathrm{him} / \mathrm{her}$. & & & & & \\
\hline 10. My manager goes beyond self-interest for the good of the group. & & & & & \\
\hline 11. My manager acts in ways that builds my respect. & & & & & \\
\hline 12. My manager displays a sense of power and confidence. & & & & & \\
\hline 13. My manager talks about his/her most important values and beliefs. & & & & & \\
\hline 14. My manager emphasizes the importance of having a collective sense of mission. & & & & & \\
\hline 15. My manager specifies the importance of having a strong sense of purpose. & & & & & \\
\hline 16. My manager considers the moral and ethical consequences of decisions. & & & & & \\
\hline Intellectual Stimulation Measure & 1 & 2 & 3 & 4 & 5 \\
\hline $\begin{array}{l}\text { 17. My manager reexamines critical assumptions in order to question whether they are } \\
\text { appropriate. }\end{array}$ & & & & & \\
\hline 18. My manager seeks differing perspectives when solving problems. & & & & & \\
\hline 19. My manager gets me to look at problems from many different angles. & & & & & \\
\hline manager suggests new ways of looking at how to complete assignments. & & & & & \\
\hline
\end{tabular}

\section{SECTION II}

Please check the number that corresponds with how involved you are in your job using the response options below.

\begin{tabular}{|c|c|c|c|c|c|}
\hline STATEMENT & \multicolumn{5}{|c|}{ SCALE } \\
\hline Vigor & 1 & 2 & 3 & 4 & 5 \\
\hline 1. When I get up in the morning, I feel like going to wor & & & & & \\
\hline 2. At my work, I feel bursting with energy. & & & & & \\
\hline 3. At my work I always persevere, even when things do & & & & & \\
\hline 4. I can continue working for very long periods of time. & & & & & \\
\hline 5. At my job, I am very mentally resilient. & & & & & \\
\hline
\end{tabular}




\begin{tabular}{|c|c|c|c|c|c|}
\hline \multicolumn{6}{|l|}{ 6. At my job I feel strong and vigorous. } \\
\hline Dedication & 1 & 2 & 3 & 4 & 5 \\
\hline \multicolumn{6}{|l|}{ 7. To me, my job is challenging. } \\
\hline \multicolumn{6}{|l|}{ 8. My job inspires me. } \\
\hline \multicolumn{6}{|l|}{ 9. I am enthusiastic about my job. } \\
\hline \multicolumn{6}{|l|}{ 10. I am proud of the work that I do. } \\
\hline \multicolumn{6}{|c|}{ 11. I find the work that I do full of meaning and purpose. } \\
\hline Absorption & 1 & 2 & 3 & 4 & 5 \\
\hline \multicolumn{6}{|c|}{ 12. When I am working, I forget everything else around me. } \\
\hline \multicolumn{6}{|l|}{ 13. Time flies when I am working. } \\
\hline \multicolumn{6}{|l|}{ 14. I get carried away when I am working. } \\
\hline \multicolumn{6}{|l|}{ 15. It is difficult to detach myself from my job. } \\
\hline \multicolumn{6}{|l|}{ 16. I am immersed in my work } \\
\hline 17. I feel happy when I am working intensely. & & & & & \\
\hline
\end{tabular}

\section{SECTION III}

The following set of questions is to get some background information about you and your supervisor. Please check the appropriate boxes for the following questions.

\section{1) Your gender:}

2) Your age:
Male
Female

Less than 35 years

35 to less than 40

40 to less than 45

45 to less than 50

More than 50 years

3) Your education:
High School
College
Post graduate
Other (

4) What is your hotel's management pattern?

Chain- Franchise

Independent

5) How many rooms in your hotel?

Less than 200 rooms

300-399 rooms

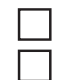

More than 500 rooms

6) Your supervisor's gender
Chain Management Contract

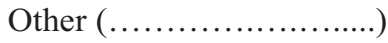

200-299 rooms

400-500 rooms 
7) Your supervisor's age:

Less than 35 years

40 to less than 45
35 to less than 40

More than 45 years

\section{Thank You for your Cooperation}

\section{قياس العلاقة بين القيادة التحويلية والاندماج الوظيفي في الفنادق}

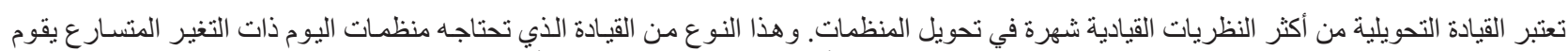

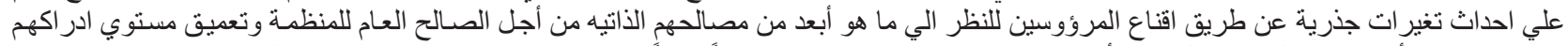

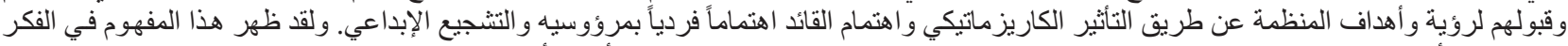

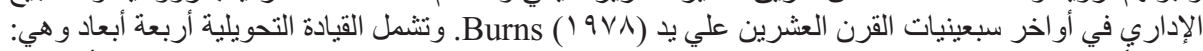

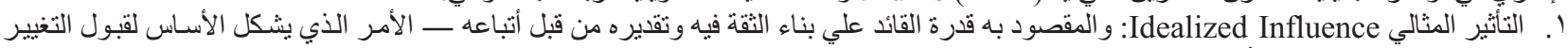

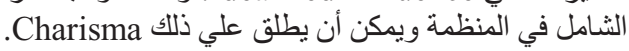

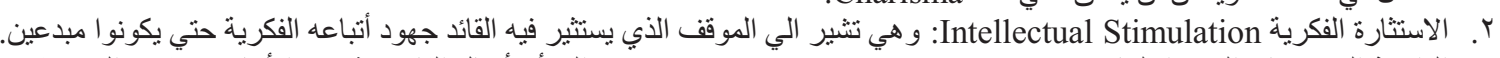

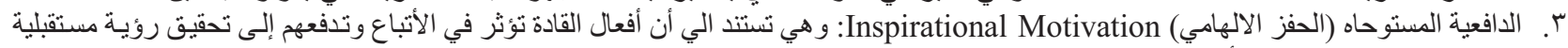

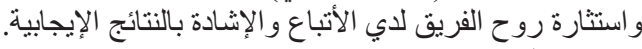

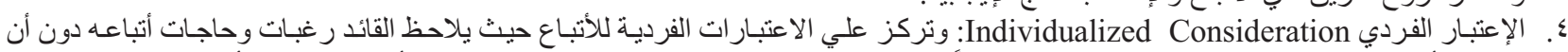

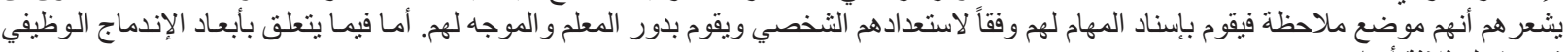
فهو يشمل ثلاثة أبعاد و هي ماني • الحيوية Vigor: وهي تلعني أنعي المستويات العالية من الطاقة الفكرية والجسدية أثناء أداء العمل.

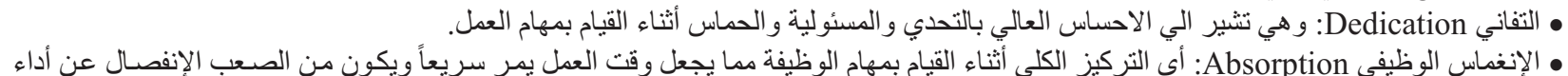

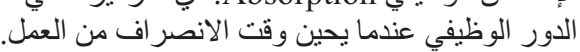

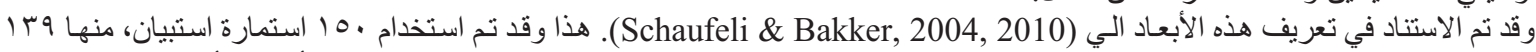

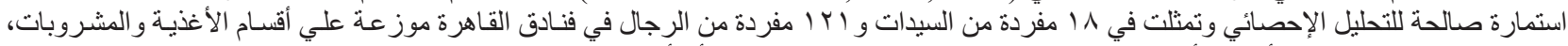

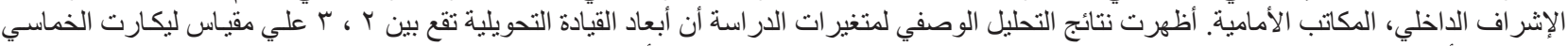

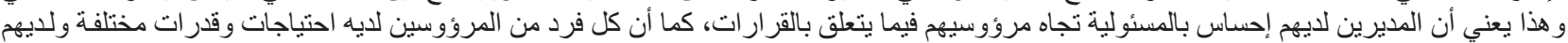

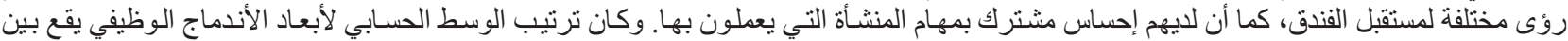

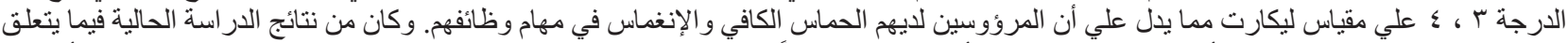

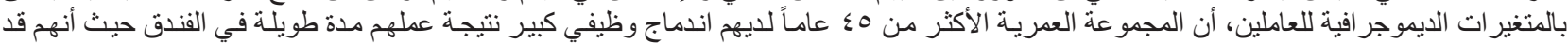

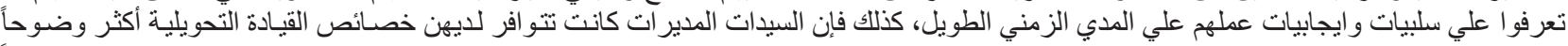

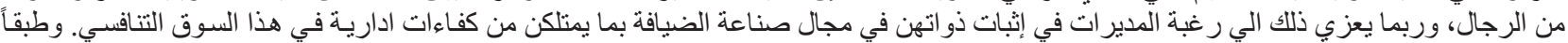

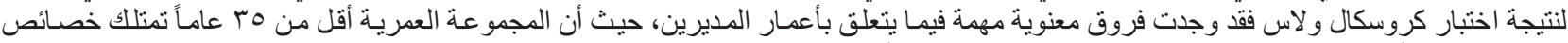

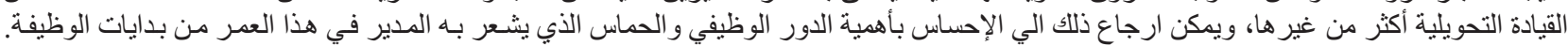

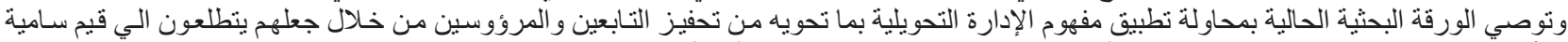

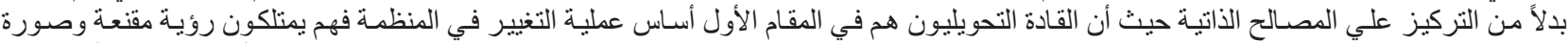

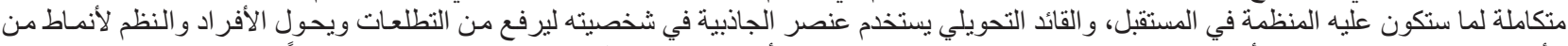

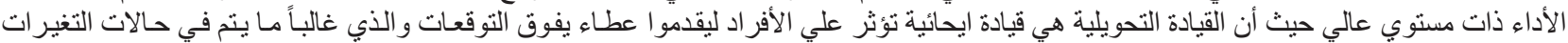

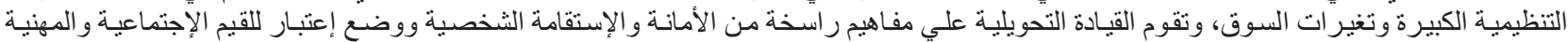

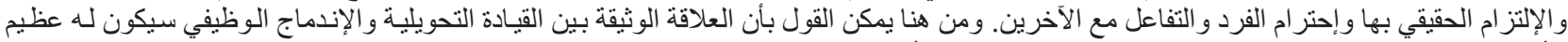

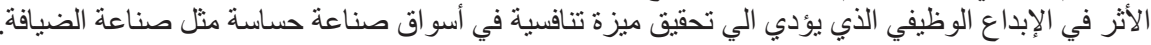

